No. Issue: 13 | Research Articles | pp. 97-100

\title{
Assessment on University Students' Financial Management Skills
}

\author{
Che Rohayu Darlynie ${ }^{1, *}$ and Hasimah Sapiri ${ }^{1}$ \\ 1 School of Quantitative Sciences, Universiti Utara Malaysia; \\ * Correspondence: ayudarlynie@gmail.com
}

Received: 4 August 2019; Accepted: 16 August 2019; Published: 30 September 2019

\begin{abstract}
Financial management defined as behavior and perceptions about how financial is managed. For the present, student financial management refers to the behavior and perceptions of how students manage their finances and handle their money during studies. The aim of this study is to assess university students' financial management skills. Data were collected among Universiti Utara Malaysia (UUM) students. The selection of this sample was students with an age between 18 years old to 25 years old. The sample was selected through the simple random sampling technique with the sample size of 114 respondents. Perceived financial management skills were measured using a Likert scale from 1 (unskilled) to 5 (skilful) on 12 management related items: daily expenses, debt, future needs, time, savings, use of education loan, purpose of education loan, social interaction, stress, decision making, problem solving and career planning. The data were analyzed by using $t$-tests and Analyses of Variances (ANOVA) through Statistical Packages for Social Sciences (SPSS) version 25. The scores for the financial management skills were computed and the results revealed there was no gender difference in the score. However, the female students showed a higher level of financial skills than the males. Therefore, there are significant differences in the mean score among ethnic groups, with Indian students scoring the lowest compared to other ethnic groups.
\end{abstract}

Keywords: Financial management skills, University students, $t$-tests, Analyses of variances

\section{Introduction}

Financial management defined as behaviour and perceptions about how financial is managed. For the present, student financial management refers to the behaviour and perceptions of how students manage their finances and handle their money during studies. Leach, Hayhoe \& Turner (1999) stated that, early exposure to financial management is important for the younger generation because they have various obligations such as paying back the loans they used for their university education even before they graduated. In fact, the student must have the important financial management knowledge and skills to ensure that he or she can achieve the objective or purpose of the loan he or she applied.

Many students experience being on their own for the first time, where is free from the comforts of home. One of the challenges facing them is to budget their spent money. Living in a university is a change from childhood to adulthood that makes life more challenging and difficult for students because they have to make decision for themselves. Many groups of student have spent their money differently, for example women tended to spend more money on clothing, while men spent more money on entertainment and food (Wang and Xiao, 2008). It looks at how students manage the money they receive from their education, whether from a scholarship, a loan or a parent. This issue should be dealt with as soon as possible in order to prevent our students from engaging in other major problems that can be caused by their initial financial problem.

Financial management issue has never been stable, especially among university students. According to Malaysia Department of Insolvency (MDI) the number of cases of bankruptcy by age group for age 25 and below increased by $42.45 \%$ from 2017 to 2018 . Therefore, it is more important than ever to analyse and evaluate young people's financial management skills, as their 
personal financial decisions will affect the economy for many years to come (Kayla Allen \& Victoria Kinchen, 2009).

According to Rafi (2016), university students' have difficulties in managing their limited financial source. Most of them are linked to ineffective financial behaviour, including low savings, poor record keeping and some students involved in credit card debt. Since the ability to manage financial sources is essential for everyday life activities. Therefore, information on financial management skills will help to reduce the number of cases of bankruptcy among young people in Malaysia and help develop economic performance in Malaysia. Therefore, it is important to assess the financial management skills of university students. Thus this study will assess university student's financial management skills. By assessing students' financial management skills, we can understand better about the knowledge concerning financial behaviour of the students.

\section{Research Methods}

\subsection{Population and Sample}

Population is defined as the number of individuals in any field enquiry under consideration. Determining a suitable sample is crucial for conducting a survey because it represents a portion of the target population (Etikan et.al, 2016). The population in this study was all the students in Universiti Utara Malaysia (UUM). The selection of this sample was students with an age between 18 years old to 25 years old. The sampling technique used in this study was simple random sampling. Based on the sampling technique above, the sample size in this study was 100 respondents.

\subsection{Measurements}

A self-administered questionnaire was used to collect the data in this study. The survey instrument included 2 sections. For section 1, it is mainly focusing on demographic background. Meanwhile, for the section 2, it contains of 12 items of financial skills. The financial management skills scale is about their management abilities of daily expenses, credit and debt, future needs, time management, savings, use of education loan, purpose of education loan, decision making, problem solving, stress management, interaction skills and career planning. The perceived financial management skills were measured by asking students to rate those 12 items. In addition, this type of measurement scale allows the items to be effortlessly quantified as well as it has the characteristics of equal measurement for all categories (Weisburd \& Britt, 2014). The target respondents were rate themselves according to the scale that represents their exact financial skills. In this study scale 1 to 5 were used, the scale was ranged from 1 which identified as unskilled to number 5 as skilful which at point 3 was labelled moderate to assist in understanding.

\subsection{Statistical Analysis}

A financial skill score was calculated by summing the average scores for all 12 statements. $t$ tests and Analyses of Variances (ANOVA) are carried out on selected demographic characteristics, to determine the differences in financial management skills among students. In this study, Statistical Packages for Social Sciences (SPSS) was used to obtain results for the data.

\section{Findings and Discussion}

Based on the 114 students studied, $43.9 \%$ were male and $56.1 \%$ were female students. The ethnic composition was Malay (82.5\%), Chinese (6.1\%), Indian (6.1\%) and others (5.3\%). The age composition of students was 18 to 21 years $(64 \%)$ and 22 to 25 years (36\%). More than half 
of the respondents (64\%) were funded by education loans, while $9.6 \%$ of the respondents received a scholarship, $10.5 \%$ used saving income which is income from their part time job and only $15.8 \%$ received money from parent or family.

Table 1. Mean score of financial skills components

\begin{tabular}{lcccc}
\hline \multicolumn{1}{c}{ Components } & Male & Female & $\boldsymbol{t}$-test & Sig. \\
\hline Manage Daily Expense & 3.78 & 3.73 & 0.241 & 0.813 \\
Credit/Debt & 3.98 & 4.11 & -0.777 & 0.132 \\
Future Needs & 4.18 & 4.34 & -0.948 & 0.719 \\
Time Management & 4.08 & 4.41 & -2.083 & 0.065 \\
Stress Management & 3.94 & 3.77 & 0.976 & 0.624 \\
Saving & 3.68 & 3.88 & -0.945 & 0.484 \\
Use of Study Loan & 4.12 & 4.25 & -0.771 & 0.993 \\
Purpose of Study Loan & 3.82 & 4.06 & -1.339 & 0.69 \\
Interaction Skills & 3.70 & 3.72 & -0.092 & 0.111 \\
Decision Making & 3.88 & 3.88 & 0.027 & 0.127 \\
Problem Solving & 3.70 & 3.78 & -0.482 & 0.238 \\
Career Planning & 4.12 & 4.13 & -0.28 & 0.482 \\
\hline Total mean score & $\mathbf{4 6 . 9 8}$ & $\mathbf{4 8 . 0 5}$ & $\mathbf{- 0 . 6 5 1}$ & $\mathbf{0 . 1 3 9}$ \\
\hline
\end{tabular}

For financial skills, eleven items were included in the questionnaire to measure the financial skills of the respondents. The respondents were asked to determine the level of their ability for each skill separately. Assessing the components of financial skills between male and female students shown in table 1 shows that male students have greater ability to manage daily spending and stress than female students. However, female students have greater ability in credit/debts, future needs, time management, savings, education loan use and purpose, interaction skills, problem solving and career planning as compared to male students. Both male and female students perceived equal abilities in their decision making. The results indicate that, female students perceived that they have a higher level of financial skills based on the total mean score than male students. Overall, average comparison analysis shows that there is no significant difference in financial skills between male and female students.

Table 2. Summary of mean comparison analysis of financial skills based on demographic factors

\begin{tabular}{|c|c|c|c|}
\hline Item & Mean & $t, F$ & Sig. \\
\hline \multicolumn{4}{|l|}{ Gender } \\
\hline Male & 46.98 & $t=-0.651$ & 0.139 \\
\hline Female & 48.05 & & \\
\hline \multicolumn{4}{|l|}{ Age } \\
\hline $18-21$ & 46.34 & $t=-2.062$ & 0.139 \\
\hline $22-25$ & 49.78 & & \\
\hline \multicolumn{4}{|l|}{ Ethnic } \\
\hline Malay & 48.43 & $F=2.119$ & 0.002 \\
\hline Chinese & 46.14 & & \\
\hline Indian & 41.43 & & \\
\hline
\end{tabular}

Based on the results shown in table 2, it shows that there is no significant difference in the level of financial skill between the ages of 18 to 21 and 22 to 25. Students aged between 22 and 25 have higher skill scores (Mean $=49.78)$ than students between 18 and 21 (Mean $=46.34$ ). Therefore, financial skills were significantly different from ethnic groups. Among the different ethnic groups, the results showed that Indian students reported the lowest level of financial skills 
(Mean $=41.43)$, Chinese $($ Mean $=46.14)$, and Malay student reported having the highest level $($ Mean $=48.43)$.

\section{Conclusions}

Most students are the recipients of educational loan in this research. Only $30 \%$ of them obtain income from other sources particularly from their parents. The data demonstrates that parents still need to support college education for their children. Educational loans assist to reduce parents ' economic burden, but long-term loans impose a financial burden on students.

Financial loans among students are a very important topic in terms to ensure that they are able to continue their study and reach out to their dream or vision. But money management process among these students is also very crucial in terms to ensure that they will have adequate economic source to complete their study. The result showed there is no significant difference in the financial skills between males and females. However, female students showed a higher level of financial skills than the males. Therefore, based on age, students with age between 22 and 25 have higher level of financial skills rather than students age between 18 and 21.

Regarding the race groups, Malaysian students have the highest level of financial skills, Chinese students are in the average level and Indian students have the lowest level. Financial skills include future planning and achievement of financial well-being. Educators should emphasize on students the importance of developing good financial management skills.

In today's high school classes, students need to learn basic financial management skills. A fundamental knowledge of credit, investment, budgeting and the development of long-term financial goals will provide students and help them to live without the stress of debt and financial difficulties that faced by many.

\section{Acknowledgement}

No authors are in conflict of interest.

\section{References}

Etikan, I., Musa, S. A., and Alkassim, R. S. 2016. Comparison of Convenience Sampling and Purposive Sampling. American Journal of Theoretical and Applied Statistics, 5, 1-4.

Leach, L.J., Hayhoe, C.R., and Turner, P.R. 1999. Factors Affecting Perceived Economic Wellbeing of College Students: A Gender Perspective. Journal of financial counselling and planning; Columbus, 10(2), 11-24.

Wang, J., Xiao, J.J. 2008. Buying Behavior, Social Support and Credit Card Indebtedness of College Students. International Journal of Consumer Studies.

Kayla Allen, Victoria Kinchen. (2009). Financial Management Practices of College Students. Global Journal of Business Research, 3(1).

Malaysia Department of Insolvency (MDI). Retrieved from http://www.mdi.gov.my/images/ documents/Statistics/Bankrupcy/StatistikKebankrapandisember2018.pdf.

Mohamad Hisyam Izzudin Mohd Rafi. 2016. Research Hub. 2(1).

Weisburd, D., \& Britt, C. L. 2014. Statistics in Criminal Justice, $3^{r d} E d$.. New York: Springer. 